\title{
ОПТИМІЗАЦІЯ ПЕРЕДСТАРТОВОЇ ГОДІВЛІ ПОРОСЯТ В УМОВАХ ІНТЕНСИВНОЇ ТЕХНОЛОГІЇ
}

\author{
Попсуй В'ячеслав Васильович \\ кандидат сільськогосподарських наук, доцент \\ Сумський національний аграрний університет \\ ORCID: 0000-0002-3487-0923 \\ E-mail:vvp72@ukr.nett \\ Корж Ольга Василівна \\ кандидат сільськогосподарських наук, доцент \\ Сумський національний аграрний університет \\ ORCID: 0000-0002-9134-5148 \\ E-mail: korg.olga@ukr.net \\ Опара Віктор Олексійович \\ кандидат сільськогосподарських наук, доцент \\ Сумський національний аграрний університет \\ ORCID: 0000-0002-8917-4423 \\ E-mail: vopara@ukr.net \\ Вербельчук Тетяна Василівна \\ кандидат сільськогосподарських наук, доцент \\ Поліський національний аграрний університет, \\ ORCID: 0000-0001-73344507, \\ E-mail: verba555@ukr.net \\ Щербина Олена Вікторівна \\ кандидат сільськогосподарських наук, доцент \\ Херсонський державний аграрно-економічний університет \\ ORCID: 0000-0003-0310-9338 \\ E-mail: lenanej@ukr.net
}

У статті проведено аналіз науково-практичних спостережень з пошуку оптимальної схеми передстартової годівлі поросят-сисунів до відлучення. Оцінено вплив двох гранульованих престартерів на енергію росту поросят, що обумовлено початком їх застосування. Об'єктом досліджень стали підсосні свиноматки та їх поросята до переводу на дорощування. При проведенні експерименту досліджували енергію росту сисунів, які вирощувались за різною схемою застосування двох марок престартерів, їхню життєздатність, також визначалася економічна доцільність застосування в умовах існуючої технології товарного репродуктору. Дослід проводився методом груп-аналогів і проходив у двох повторах. Особливість експерименту в тому, що поросятам контрольної групи, починаючи з сьомої доби життя, згодовували комбікорм Diamante Premium Престарт (рецептура і технологія компанії Фідлайн), який використовувався в той час у ТОВ НВП «Глобинський свинокомплекс» для підгодівлі поросят. Емпірично доведена технологічна та економічна доцільність використання суперпрестартеру "Koudijs D-Mіх» з дводенного віку і поступовою заміною його з 14 дня комбікормом Diamante Premium Престарт. Інноваційна для підприємства схема підгодівлі сприяла збільшенню середньої маси гнізд свиноматок при відлученні у 21 день на 10,5\%, збереженості поросят, яка покращилася на 5,2\%, та зменшенню витрат передстартових кормів на $5 \%$.

Ключові слова: передстартовий комбікорм, престартер, поросята-сисуни, відлучення поросят, середньодобові прирости, маса гнізда при відлученні, витрати корму, збереженість

DOI: https://doi.org/10.32845/bsnau.Ivst.2021.4.24

В Україні наразі поступово проходить реновація інтенсивного свинарства. Якщо в сімдесяті роки минулого століття при впровадженні промислових технологій нахил робився на концентрацію поголів'я, спеціалізацію виробничих підрозділів, механізацію та аналогову автоматизацію технологічних процесів на спеціалізованих свинарських комплексах, то зараз проходить осучаснення технологій з використанням науково- технологічних здобутків в суміжних біологічних науках (генетика, біохімія, молекулярна біологія та ін.) та ІТ-технологій[3, 12].

Широке застосування сучасних методів відбору

племінних тварин із застосуванням інноваційних методів раннього прогнозування продуктивності та направленої селекції за найбільш важливими господарсько-корисними ознаками дозволило селекційно-генетичним компаніям створити спеціалізовані материнські та батьківські термінальні лінії. Фінальні гібридні підсвинки, отримані при їх поєднанні, спроможні досягати 100 кг живої маси в середньому до 160 днів, витрачаючи 2,5-3 кг корму на кілограм приросту. Лінійні свиноматки, від яких отримані поросята, спроможні народжувати та відгодовувати до 16 поросят, а оптимізована система їх стартового вирощування дозволяє скоротити

Вісник Сумського національного аграрного університету 
час контактування з матерями до 3-4 тижнів[1, 14, 17]. Найважливішим стримуючим фактором такого раннього відлучення поросят $€$ здатність їх незрілого травного тракту пристосуватися до нових кормів. Тому без привчання поросят до першого корму, крім молока матері, - передстартового комбікорму, в найкоротші строки після народження неможливо впровадити цей технологічний засіб $[2,15,18]$.

Сучасний повнораціонний гранульований комбікорм для поросят - престартер - містить всі необхідні корисні речовини, що сприяє розвитку їх травної системи і проявляється у більш інтенсивному рості. Смак та запах повинен нагадувати поросятам-сисунам запах молока матері і сприяти його поїданню ними. Склад цього початкового корму збалансований таким чином, щоб також допомогти поросятам перебороти найвідповідальніший період в їхньому житті, а саме - відлучення від матері, зменшити кормовий стрес. Для захисту кишечнику та сприяння розвитку ворсинок і розвитку сприятливої мікрофрлори кишечника до складу корму вводяться пробіотики, пребіотики та молочний цукор. Високий вміст та оптимальне співвідношення енергії, легкоперетравного білку, в тому числі незамінних амінокислот, вітамінів та мінералів дозволяють забезпечити високі темпи росту молодняку і досягати запланованих приростів, а смакові та ароматизовані домішки - підвищити швидкість привчання та збільшити споживання гранульованого повнораціонного комбікорму $[4,5,11]$.

Перевагами використання таких початкових комбікормів є ї технологічність при використанні, логістична зручність при транспортуванні і зберіганні, а результатом використання - оптимізація і прогнозування росту поросят, що максимально розкриває їхній генетичний потенціал [8, 14]. Але, незважаючи на подібність у складі багаточисленних комбікормів-аналогів, їхня ефективність проявляється порізному і часто залежить від технологічних особливостей підприємства та генетичної належності тварин. Тому кожне підприємство по-своєму вирішує питання вибору постачальника престартеру $[6,9]$. Для когось головним чинником $€$ стартова можливість поросят та їх життєздатність, а хтось 3 виробничників вважає, що основною перевагою цього корму повинна бути відносно невисока вартість або витрати при вирощуванні поросят-сисунів [7, 10, 13].

3 огляду на це, метою наших досліджень став пошук оптимального варіанту престартової годівлі поросят при відлученні їх у три тижні в умовах товарного репродуктору № 1 ТОВ «Глобинський свинокомплекс». Особливістю підприємства є те, що воно використовує лінійне високотехнологічне продуктивне поголів'я селекційно-генетичної компанії PIC з Ірландії. Нуклеуксні ферми, з яких завезене батьківське стадо, практично позбавлені багатьох свинячих патогенних мікроорганізмів і характеризуються з точки зору біологічної безпеки високим ветеринарним статусом. Тому, незважаючи на високий продуктивний потенціал, тварини дуже чутливі до технологічних умов експлуатації.

Матеріали та методи досліджень. Об'єктом досліджень стали підсосні свиноматки та їх поросята до переводу на дорощування. При реалізації експерименту досліджували енергію росту сисунів, які вирощувались за різною схемою застосування двох марок престартерів, їхню життєздатність, також визначалася економічна доцільність застосування в умовах існуючої технології товарного репродуктору. Згідно зі схемою дослідів, свиноматки, яких було 436 голів, були поділені на дві групи. Дослід проводився методом груп-аналогів і проходив у двох повторах. Основних свиноматок підбирали за кількістю опоросів та враховували попередню продуктивність. Середня багатоплідність свиноматок становила 12 голів. Особливість експерименту в тому, що поросятам контрольної групи, починаючи з сьомої доби життя, згодовували комбікорм Diamante Premium Престарт (рецептура і технологія компанії Фідлайн), який використовувався в той час у ТОВ НВП «Глобинський свинокомплекс» для підгодівлі поросят. Їх ровесників з другої дослідної групи з другої доби життя привчали до суперпрестартерного комбікорму «Премілк для поросят», рецептура та склад якого розроблені відомою транснаціональною фірмою Каудайс (Нідерланди), з поступовим переведенням їх з 14 по 18 добу життя на престартерний комбікорм- Diamante Premium Престарт. Витрати цього комбікорму та суперпрестартеру «Koudijs D-Mix» проводилися відповідно до схеми, прийнятої в господарстві, з орієнтацією на рекомендації розробників рецептури (табл.1). Слід зазначити, що в таблиці наведено розрахункові показники, а реальне споживання комбікормів може змінюватись в залежності від молочності маток, жвавості й апетиту поросят та стану їх здоров'я.

Схема привчання до корму і годівлі поросят сисунів і на дорощуванні (г/доба).

\begin{tabular}{|c|c|c|c|}
\hline \multirow{3}{*}{ Віковий період поросят, дн. } & \multicolumn{3}{|c|}{ група } \\
\hline & 1 & & \\
\hline & Престартер «Діамант» & Престартер «Діамант» & Суперпрестартер «Каудайс» \\
\hline $2-4$ & - & - & 10 \\
\hline $5-7$ & 20 & - & 20 \\
\hline $8-13$ & 80 & - & 60 \\
\hline 14-17 & 110 & 80 & 30 \\
\hline $18-21$ & 150 & 150 & - \\
\hline Витрати корму, кг за період/голова & 1480 & 860 & 560 \\
\hline
\end{tabular}

Результати досліджень. Проведені два експерименти показали схожі тенденції у прояві результатів. Деякі показники в першій серії дослідів проявилися більш рельє- фно, ніж у другому, та навпаки. У таблиці 2 наведено узагальнені результати емпіричних спостережень. 
Таблиця 2

Результати досліду з порівняльного використання передстартерів для поросят на товарному репродукторі

\begin{tabular}{|c|c|c|}
\hline Показники & $\begin{array}{c}1 \text { група } \\
\text { (престартер «Діамант») }\end{array}$ & $\begin{array}{c}2 \text { група } \\
\text { (суперпрестартер «Каудайс» + «Діамант») }\end{array}$ \\
\hline Кількість свиноматок в групі, гол. & 218 & 218 \\
\hline Отримано поросят, голів & 2775 & 2761 \\
\hline Багатоплідність, в середньому поросят на 1 опорос, гол. & $12,70 \pm 0,43$ & $12,67 \pm 0,54$ \\
\hline Відлучено поросят, гол., гніздо & $11,17 \pm 0,26$ & 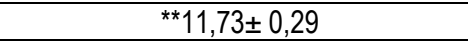 \\
\hline Збереженість при відлученні в 21 день, \% & 88,0 & 92,6 \\
\hline Середня маса 1 голови при відлученні, кг & 5,55 & 6,08 \\
\hline Середня маса гнізда поросят при відлученні в 21 добу, кг & $62,20 \pm 1,6$ & ${ }^{* *} 68,65 \pm 1,9$ \\
\hline Середньодобовий приріст, г & 199,8 & 206,9 \\
\hline Спожито комбікорму «Діамант», кг/гол & 1,64 & 1,17 \\
\hline Спожито комбікорму «Каудайз», кг/гол & - & 0,36 \\
\hline Спожито передстартеру, на постановочну голову, кг & 1,53 & 1,36 \\
\hline Спожито передстартеру, кг/гол на відлучену & 1,64 & 1,53 \\
\hline Середні витрати престартеру на 1 кг приросту, кг & 0,40 & 0,38 \\
\hline
\end{tabular}

За їх результатами встановлено, що в обох групах багатоплідність свиноматок перебувала на практично одному рівні, що вказує на високий прояв цієї відтворювальної ознаки у них та рівні стартові можливості тварин у кожній групі. У підсисний період спостерігалася тенденція до покращення життєздатності поросят дослідної групи. У контрольній групі збереженість поросят склала 88,0\%, тоді як в дослідній вона виявилась на 5,2\% кращою. До відлучення у контрольній групі залишилось у середньому 11,17 поросят, тоді як в дослідній, за рахунок кращої збереженості, їх було у середньому на 0,56 голови у гнізді більше $(P>0,99)$. Сисуни 3 цієї групи більш енергійно розвивалися, а їх середньодобовий приріст до часу відлучення був на 3,5\% більшим, ніж у ровесників у контрольній групі. Більша енергія росту поросят у поєднанні з кращою їх збереженістю проявилася у більш масивних гніздах свиноматок при відлученні. Переважуван- ня гнізд у 21 день показала, що молочність свиноматок була на 10,5\% достовірно більшою в дослідній групі, де поросята з другого дня життя привчалися до нового корму. При цьому перевитрат престартових кормів в дослідній групі не виявлено, а навпаки середні витрати корму на 1 кг приросту були на 5\% меншими. Результати розрахунків вважаємо не повними, тому що потрібно враховувати і подальшу енергію росту та збереженість поросят, за якими проводилися спостереження. У дослідах також не враховувалось споживання і поживність повнораціонного комбікорму підсосними свиноматками, що при годівлі «досхочу» також могло вплинути на їх молочність.

У таблиці 3 наведені результати обрахунків визначення економічної доцільності переходу на іншу технологічну схему привчання і годівлі підсосних поросят на свинокомплексі ГК «Глобино» на час проведення експерименту.

Таблиця 3

Розрахунок економічної ефективності від застосування різних схем передстартової годівлі поросят-сисунів

\begin{tabular}{|l|c|c|}
\hline \multicolumn{1}{|c|}{ Показники } & \multicolumn{2}{|c|}{ Група } \\
\cline { 2 - 3 } & \multicolumn{1}{|c|}{ I( (пропонується) } \\
\hline Середня маса гнізда при відлученні,кг & 62,20 & 68,65 \\
\hline Середня маса поросяти при відлученні, кг & 5,55 & 6,08 \\
\hline Виробнича собівартість приросту поросят на дільниці відтворення, грн/кг & \multicolumn{2}{|c|}{80,76} \\
\hline Собівартість приросту сисунів грн /кг & 448,22 & 491,02 \\
\hline +/- до базового варіанту & - & $+42,80$ \\
\hline Витрати корму, грн /гол & & \\
\hline «Діамант» & 1,64 & 1,17 \\
\hline «Каудайз» & - & 0,36 \\
\hline Витрати на престартери, грн /гол, в т. ч. & 22,53 & 22,78 \\
\hline «Діамант» & 22,53 & 16,08 \\
\hline «Каудайз» & - & 6,7 \\
\hline Загальні витрати на престартери, грн / гніздо & 257,19 \\
\hline +/- до базового варіанту & 251,66 & $-5,53$ \\
\hline Прибуток від запровадження інновації в годівлі грн/порося & - & $+37,27$ \\
\hline Прибуток від запровадження інновації грн./ гніздо & - & 420,77 \\
\hline
\end{tabular}

Аналітично підтверджено, що годівля свиней кормовими засобами, які виготовлені за сучасними технологіями, $€$ доцільною, потребує впровадження у виробничий процес для сприяння інтенсисікації репродукції свиней. Прибуток від запровадження інноваційної схеми годівлі, комбінації престартерів «Diamant» та Koudijs становить 420,8 грн. на гніздо при відлученні у 21 день і передачі на дорощування. Слід зазначити, що «Diamant Premium» виробляється на власному комбікормовому заводі за рецептурою, технологі- єю і участю компанії Фрідлайн, а престартер Коудайз вироблено на заводі D-Mix у Львівській області.

Висновки

1. Повнораціонні передстартові корми для підсисних поросят на комплексі забезпечують інтенсивність стартового росту поросят. Їх використання ефективне, дозволяє розкривати генетичний потенціал тварин та в цілому сприяє інтенсифрікації репродукції свиней на підприємстві.

2. Високий вміст легкоперетравних збалансованих 
компонентів у гранульованому суперпередстартовому повнораціонному комбікормі, що виготовлений компанією «DМікс» за рецептурою Koudijs Anima INutrition, дозволяє сисунам легше переносити харчові стреси в підсисний період, а також підготувати їх до відлучення від свиноматки у тритижневому віці.
3. Комбінована схема підгодівлі поросят-сисунів з використанням двох престартерів сприяла збільшенню середньої маси гнізд свиноматок при відлученні у 21 день на 10,5, збереженості поросят на 5,2 і зменшенню витрат передстартових кормів на одиницю приросту на $5 \%$.

\section{Список використаної літератури:}

1. Волощук В. М., Іванов В. О. Біологія свиней: навч. посіб. К., 2009. 304 с.

2. Засуха Ю.В. Поведінка, споживання кормів, ріст та розміри шлунку поросят у залежності від режиму їх підсису. Вісник Полтавської державної аграрної академії. 2004. № 2. С. 18-21.

3. Жижка С. В., Повод М. Г. Вплив систем вентиляції негативного та рівномірного тиску в свинарниках для підсисних свиноматок ірландського походження на їх відтворювальні якості. Вісник Сумського національного аграрного університету. Серія : Тваринництво. 2020. Вип. 1. С. 49-58.

4. Морару И. Кормление свиней : практ. пособ. К. : АграрМедиенУкраина, 2011. 333 с.

5. Норми годівлі, раціони і поживність кормів для різних видів сільськогосподарських тварин : довідник / [Г. В. Проваторов, В. І. Ладика, Л. В. Бондарчук та ін.]. Суми : ТОВ «ВТД «Університетська книга», 2007. 488

6. Оглобля В. В., Повод М. Г. Відтворювальні якості свиноматок ірландського походження за чистопородного розведення та схрещування в умовах промислового комплексу. Вісник Сумського національного аграрного університету. Серія : Тваринництво. 2020. Вип. 1, С. 103-107.

7. Подобед, Л.И. Интенсивное выращивание поросят (Технологические основы кормления и содержания, профілактика продукционных нарушений). Киев: ПолиграфИнко, 2010. 288 с.

8. Поліщук А. А., Булавкіна Т. П. Сучасні кормові добавки в годівлі тварин та птиці. Сільське господарство. Тваринництво. 2010. № 12. С. 63-67.

9. Попсуй В. В., Салогуб А. М., Опара В. О., Буднік В. М. Ефективність запровадження в технологію вирощування поросят - сисунів кормових засобів фірми Шауманн. Вісник Сумського національного аграрного університету. Серія "Тваринництво" : науково-методичний журнал. 2008. №6, С. 104-110.

10. Попсуй В., Опара В. Генетичні задатки свиней та умови для їхньої реалізації. AGROEXPERT : практичний посібник аграрія. 2016. №8, С. 74-76.

11. Проваторов Г.В., Проваторов В.О.. Годівля сільськогосподарських тварин: Підручник. Суми ВТД «Університетська книга», 2004. $510 \mathrm{c}$.

12. Рекомендації. Сучасні технології годівлі свиней / А.А. Гетя, В.Ф. Петриченко, В.Н. Тимченко, та ін. Полтава: Інститут свинарства НААНУ. 2010. 84 с

13. Седіло Г. М., Вовк С. О., Пундик В. П., Тесак Г. В. Особливості підгодівлі поросят перед відлученням від свиноматок. Передгірне та гірське землеробство і тваринництво. 2014. Вип. 56(2), С. 175-181.

14. Скварук В. С., Лівак І. І., Равлик О. М. Вирощування поросят на промислових комплексах. Львів : [Б. в.], 1990. 34 с.

15. Сурай П. Ф., Фотина Т. И. Отъем поросят и престартерно екормление: от теории к практике. Корма и кормление. 2014. № 1, С. 2 - 10

16. Церенюк О.М., Акімов О.В., Тимофієнко І.М. Підвищення стресостійкості свиней http://agrobusiness.com.ua/agro/suchasnetvarynnytstvo/item/8054-pidvyshchennia-stresostiikosti-svynei.html/(дата звернення: 20.04.2017).

17. Шпетний М. Б., Повод М. Г. Вплив паратипових факторів на продуктивність поросят після відлучення в умовах промислової технології виробництва свинини. Вісник Сумського НАУ. Серія «Тваринництво». 2018. № 7 (35), С. $166-171$.

18. Юлевич О. І., Лихач А. В., Дехтяр Ю. Ф. Оцінка залежності показників росту підсисних та відлучених поросят від складу раціонів. Науково-технічний бюлетень. 2016. № 115. С. 258-263.

\section{References:}

1. Voloshchuk V. M., Ivanov V. O., 2009. Biolohiia svynei: navch. Posib [Biology of pigs: textbook. way]. M. : Kolos.

2. Zasukha Yu.V., 2004. Povedinka, spozhyvannia kormiv, rist ta rozmiry shlunku porosiat u zalezhnosti vid rezhymu yikh pidsysu [Biology of pigs: textbook. Behavior, feed consumption, growth and size of the stomach of piglets, depending on the mode of their sucking // Visnyk Poltavskoi derzhavnoi ahrarnoi akademii]. Bulletin of the Poltava State Agrarian Academy, issue 2, pp.18-21.

3. Zhyzhka S. V., Povod M. G. 2020., Vplyv system ventyliatsii nehatyvnoho ta rivnomirnoho tysku v svynarnykakh dlia pidsysnykh svynomatok irlandskoho pokhodzhennia na yikh vidtvoriuvalni yakosti [Influence of negative and uniform pressure ventilation systems in piggeries for suckling sows of Irish origin on their reproductive qualities]. Bulletin of Sumy National Agrarian University. Series: Livestock, issue 1, pp. 49-58.

4. Moraru Y., 2011. Kormlenye svynei : prakt. posob [Feeding pigs: practice. allowance]. M. : AgrarianMedienUkraine.

5. Provatorov G. V., 2007. Normy hodivli, ratsiony i pozhyvnist kormiv dlia riznykh vydiv silskohospodarskykh tvaryn : dovidnyk [Feeding rates, rations and nutritional value of feed for different species of farm animals: a guide]. Sums: VTD University Book LLC.

6. Ohloblia V. V., Povod M. G. 2020. Vidtvoriuvalni yakosti svynomatok irlandskoho pokhodzhennia za chystoporodnoho rozvedennia ta skhreshchuvannia $v$ umovakh promyslovoho kompleksu [Reproductive qualities of sows of Irish origin in purebred breeding and crossing in the conditions of an industrial complex]. Bulletin of Sumy National Agrarian University. Series: Livestock, issue 1., pp. 103-107. 
7. Podobed, L.Y., 2010. Yntensyvnoe vыrashchyvanye porosiat (Tekhnolohycheskye osnovы kormlenyia y soderzhanyia, profilaktyka produktsyonnыkh narushenyi) [Intensive rearing of piglets (Technological bases of feeding and maintenance, prevention of production disorders)]. Kyev.

8. Polishchuk A. A., 2010. Suchasni kormovi dobavky v hodivli tvaryn ta ptytsi [Modern feed additives in animal and poultry feeding]. Agriculture. Livestock, issue 12, pp. 63 - 67.

9. Popsui V. V., Salohub A. M., Opara V. O., Budnik V. M., 2008. Efektyvnist zaprovadzhennia v tekhnolohiiu vyroshchuvannia porosiat - sysuniv kormovykh zasobiv firmy Shaumann [The effectiveness of the introduction into the technology of breeding piglets - suckers feed Schaumann]. Bulletin of Sumy National Agrarian University. Series: Livestock, issue 6, pp. 104 - 110.

10. Popsui V. V., Opara V. O., 2016. Henetychni zadatky svynei ta umovy dlia yikhnoi realizatsii [Genetic traits of pigs and conditions for their implementation]. AGROEXPERT : praktychnyi posibnyk ahrariia, issue 8, pp. 74-76.

11. Provatorov H.V., Provatorov V.O., 2004. Hodivlia silskohospodarskykh tvaryn [Feeding farm animals]. Sumy.

12. Hetia A.A., Petrychenko V.F., Tymchenko V.N., 2010. Rekomendatsii. Suchasni tekhnolohii hodivli svynei [Recommendations. Modern technologies of feeding pigs]. Poltava.

13. Sedilo H. M., Vovk S. O., Pundyk V. P., H. V. Tesak H. V., 2014. Osoblyvosti pidhodivli porosiat pered vidluchenniam vid svynomatok [Features of feeding piglets before weaning from sows]. Foothill and mountain agriculture and animal husbandry, issue $56(2)$, pp. $175-181$

14. Skvaruk V. S., Livak I. I., O. M. Ravlyk O. M., 1990. Vyroshchuvannia porosiat na promyslovykh kompleksakh [Raising piglets on industrial complexes].Lviv.

15. Surai P. F., 2014. Otъem porosiat y prestarterno ekormlenye: ot teoryy k praktyke [Weaning of piglets and pre-starter feeding: from theory to practice]. Feed and feeding, issue 1, pp. 2 - 10/

16. Pidvyshchennia stresostiikosti svynei: veb-sait. URL: $\underline{\text { http://agro- }}$ business.com.ua/agro/suchasnetvarynnytstvo/item/8054-pidvyshchennia-stresostiikosti-svynei.html/ [Aaccessed 20.04.2017].

17. Shpetnyi M. B., Povod M. H., 2018. Vplyv paratypovykh faktoriv na produktyvnist porosiat pislia vidluchennia v umovakh promyslovoi tekhnolohii vyrobnytstva svynyny [Influence of paratypic factors on productivity of piglets after weaning in the conditions of industrial technology of pork production]. Bulletin of Sumy National Agrarian University. Series: Livestock, issue 7 (35). pp. 166171.

18. Yulevich O. I., Likhach A.V., Dekhtyar Y.F., 2016. Otsinka zalezhnosti pokaznykiv rostu pidsysnykh ta vidluchenykh porosiat vid skladu ratsioniv [Estimation of dependence of growth indicators of suckling and weaned piglets on the composition of rations ]. Scientific and technical bulletin rations, issue 115, pp. 258-263.

Popsui Viacheslav Vasylovych, PhD of Agricultural Sciences, Docent

Opara Viktor Oleksiiovych, PhD of Agricultural Sciences, Docent

Korzh Olha Vasylivna, PhD of Agricultural Sciences, Docent

Sumy National Agrarian University

Verbelchuk Tetiana Vasylivna, PhD of Agricultural Sciences, Docent, Polissya National Agrarian University

Shcherbyna Olena Viktorivna, PhD of Agricultural Sciences, Docent, Kherson State Agrarian and Economic University

Optimization of pre-start feeding of piglets in the conditions of intensive technology

The article analyzes the scientific and practical observations on finding the optimal scheme of pre-start feeding of suckling piglets before weaning. The effect of two granular prestarters on the growth energy of piglets was estimated, which is due to the beginning of their use. Suckling sows and their piglets were transferred to rearing. The experiment investigated the growth energy of mammals bred according to different schemes of application of two brands of prestarters, their viability, and also determined the economic feasibility of use in the existing technology of commercial reproducer. The experiment was performed by the method of analogous groups and took place in duplicate. The peculiarity of the experiment is that the piglets of the control group, from the seventh day of life, were fed Diamante Premium Prestart compound feed (Fidline recipe and technology), which was used at that time at Globinsky Pig Complex for feeding piglets. The technological and economic expediency of using the Koudijs D-Mix superprestarter from the age of two days and gradually replacing it with Diamante Premium Prestart compound feed from the 14th day has been empirically proven. Innovative for the company feeding scheme helped to increase the average weight of sows' nests when weaned at 21 days by 10.5, the safety of piglets improved by 5.2 and reduced the cost of pre-start feed by $5 \%$.

Key words: pre-start compound feed, prestarter, suckling piglets, weaning of piglets, average daily gains, nest weight at weaning, feed costs, safety of piglets.

Дата надходження до редакції: 03.12.2021 р. 